\title{
Cerai Gugat di Kota Cilegon
}

\author{
Agus Mulyono \\ Puslitbang Bimas Agama dan Layanan Keagamaan, Balitbang dan Diklat Kemenag RI \\ agsmuel@gmail.com \\ Artikel diterima 18 Mei, diseleksi 7 Juli, dan disetujui 28 Juli 2017
}

\begin{abstract}
This research focuses on the phenomenon of cerai gugat (divorce sued by wife) in Cilegon town. Based on the qualitative approach, this research has conducted deep interview as data collection method with women sueing divorce, officers within Religious Court and Ministry of Religious Affairs, as well as public religious figures in Cilegon. The socio-economic circunstance of Cilegon society is influential to the patterns of divorce. The divorces are strongly linked to the readiness to face modernity. Economy as one of important variables of modern society has become one of the problems of divorce. Cilegon osciety is categorised as a semi-modern society as Cilegon is one of the centres of government and economic movement. The society must adapt themselves with the context social change which mostly determines and creates them to have pragmatic and realistic orientation of life. They would maintain their life as long as they survive and enjoy life within modernity. The contrary will happen otherwise. If they could establish and exist in the context of social change, they would survive and maintain their family household. Otherwise, divorce is an alternative.
\end{abstract}

Keywords: Marriage, Family, Divorce Sues, Suscatin, Cilegon City.

\begin{abstract}
Abstrak
Penelitian ini difokuskan untuk mengkaji fenomena terjadinya cerai gugat di Kota Cilegon. Penelitian dilakukan dengan pendekatan kualitatif, metode pengumpulan data menggunakan wawancara mendalam dan observasi. Informan kunci antara lain perempuan yang melakukan cerai gugat, para pejabat di lingkungan Pengadilan Agama dan Kementerian Agama, serta tokoh agama Islam di Kota Cilegon. Kondisi sosial dan ekonomi masyarakat Kota Cilegon sangat berpengaruh terhadap pola perceraian di masyarakat Cilegon. Tindakan perceraian yang dilakukan oleh sebagian masyarakat Cilegon sangat berkaitan dengan kesiapan menghadapi modernisasi. Ekonomi adalah salah satu variabel penting bagi masyarakat modern, ternyata ia telah menjadi salah satu problem perceraian. Penduduk Kota Cilegon termasuk ke dalam kategori masyarakat semi modern, di mana daerah ini merupakan pusat pemerintahan maupun pusat pergerakan ekonomi. Menjadi suatu keharusan bagi penduduk dan masyarakatnya untuk menyesuaikan diri dengan konteks perubahan sosial. Konteks sosial inilah yang pada akhirnya banyak membentuk masyarakat Kota Cilegon untuk memiliki orientasi hidup yang pragmatis dan realistis. Sejauh ia bertahan dan hidup nikmat di dalam modernitas, ia akan tetap terjaga dan pertahankan, begitu pula sebaliknya. Jika mereka mapan dan bisa eksis dalam konteks perubahan sosial, mereka akan tetap bertahan melestarikan hidup rumah tangga dan jika tidak, maka perceraian adalah jalan alternatifnya.
\end{abstract}

Kata kunci: Pernikahan, Keluarga, Cerai Gugat, Suscatin, Kota Cilegon. 


\section{Pendahuluan}

Menurut Kompilasi Hukum Islam perkawinan adalah pernikahan, yaitu akad yang sangat kuat atau mitsaaqan ghaliizhan untuk mentaati perintah Allah dan melaksanakannya merupakan ibadah. Sementara menurut Mubarok akad adalah mempertemukan dua hal atau mengukuhkan dua pihak dalam ikatan suami istri (akad nikah). (Mubarok, 2007: 116) Nikah juga dapat diartikan sebagai bersenang-senang. Menurut ulama Hanabilah, nikah adalah akad dengan lafaz nikah atau kawin untuk mendapatkan manfaat bersenangsenang kesenangan itu bersifat rohani yang merupakan kesenangan yang tidak mungkin didapat oleh suami kecuali dalam diri seorang istri. (Nazara, 2011: 18) Oleh karena itu, pernikahan merupakan fitrah manusia untuk menyalurkan naluri kemanusiaan yang telah dihalalkan menurut syariat islam, ia juga tempat untuk menanam benih keturunan, menentramkan jiwa, kesenangan hidup dan menjaga kehormatan. Selain itu pernikan juga sebagai benteng yang kuat untuk menghindari dari kemaksiatan dan sebagai tempat untuk memperoleh keturunan yang memberikan manfaat kepada kehidupan manusia.

Menurut Undang-Undang Perkawinan Nomor 1 tahun 1974, Perkawinan adalah ikatan lahir batin antara seorang pria dengan seorang wanita sebagai suami istri dengan tujuan membentuk keluarga (rumah tangga) yang bahagia dan kekal berdasarkan Ketuhanan Yang Maha Esa.

Perceraian adalah cerai hidup atau perpisahan hidup antara pasangan suami istri sebagai akibat dari kegagalan mereka menjalankan obligasi peran masingmasing. Dalam hal ini perceraian dilihat sebagai akhir dari suatu ketidakstabilan perkawinan dimana pasangan suami istri kemudian hidup terpisah dan secara resmi diakui oleh hukum yang berlaku.
(Karim, 1999: 135) Perceraian merupakan terputusnya keluarga karena salah satu atau kedua pasangan memutuskan untuk saling meninggalkan sehingga mereka berhenti melakukan kewajibannya sebagai suami istri.

Menurut UU perkawinan, perceraian terjadi apabila kedua belah pihak baik suami maupun istri sudah sama-sama merasakan ketidakcocokan dalam menjalani rumah tangga. Undangundang Nomor 1 Tahun 1974 tentang perkawinan tidak memberikan definisi mengenai perceraian secara khusus. Pasal 39 ayat (2) UU Perkawinan serta penjelasannya secara kelas menyatakan bahwa perceraian dapat dilakukan apabila sesuai dengan alasan-alasan yang telah ditentukan. Definisi perceraian di Pengadilan Agama itu, dilihat dari putusnya perkawinan. Putusnya perkawinan di UUP dijelaskan, yaitu: karena kematian; karena perceraian; dan karena putusnya pengadilan.

Tingginya angka perceraian jenis gugat cerai yang mencapai lebih dari $100 \%$ dari jumlah cerai talak memberikan berbagai dugaan terkait posisi dan relasi laki-laki dan perempuan dalam rumah tangga. (Karim, 1999: 135) Mungkinkah tingginya angka cerai gugat merefleksikan relasi laki-laki dan perempuan lebih baik karena perempuan telah mengetahui hak-hak dirinya dan berani keluar dari situasi yang tidak menguntungkan bagi dirinya; ataukah justru menunjukkan lemahnya institusi dan lembaga-lembaga negara dan masyarakat yang memberikan layanan pembinaan rumah tangga; atau bahkan merefleksikan krisisnya pemahaman dan kesadaran masyarakat terhadap makna dan tujuan dari sebuah perkawinan dilangsungkan. Oleh karena itulah, penelitian ini dilakukan dengan menfokuskan pada tiga pertanyaan mendasar, yaitu apa saja alasanalasan dari istri sehingga memutuskan melakukan cerai gugat? apakah dampak 
dari cerai gugat yang dialami keluarga pasangan tersebut, dan bagaimana struktur sosial merespon terjadinya cerai gugat?. Dengan demikian, penelitian ini diharapkan dapat memberikan masukan kongkrit bagi upaya memperkuat institusi perkawinan yang sejalan dengan tujuan perkawinan yang tertuang di dalam UU Nomor 1 Tahun 1974 tentang Perkawinan. Secara khusus, penelitian ini diharapkan menjadi rujukan dalam pengembangan dan strategi program serta penyusunan kebijakan yang dilakukan oleh Kementerian Agama RI dan lembaga lainnya.

\section{Kerangka Teoritik}

Kerangka teoritik yang dapat dipakai untuk melihat adanya disharmoni dalam keluarga adalah teori strukturalfungsional. Teori ini dikembangkan antara lain oleh Parson (1937) dan Merton (1957). Parson dalam teorinya menyebut empat faktor penting yang mempengaruhi tindakan individu, yaitu: 1) organisme perilaku, adalah sistem tindakan yang melaksanakan fungsi ad aptasi diri dengan menyesuaikan dengan mengubah lingkungan eksternal. 2) sistem kepribadian, adalah sistem tindakan yang melaksanakan fungsi pencapaian tujuan dengan memobilisasi sumber daya yang ada untuk mencapai tujuannya. 3) sistem sosial, adalah sistem tindakan yang melaksanakan fungsi integrasi dengan mengendalikan bagianbagian yang menjadi komponennya. Dan 4) sistem kultur, adalah sistem tindakan yang melaksanakan fungsi pemeliharaan pola dengan menyediakan seperangkat norma dan nilai yang memotivasi mereka untuk bertindak. (Ritzer, 2004: 121-122)

Teori Fungsionalisme melihat bahwa masyarakat seperti organisme hidup. Setiap organ yang ada dalam organisme itu senantiasa harus berfungsi terhadap yang lain. Apabila terdapat organ yang sakit maka organ tubuh lainnya akan terganggu dan tidak berfungsi dengan baik. Fungsionalisme mengatakan bahwa dalam masyarakat (dalam kajian ini keluarga) terdapat struktur sosial yang memiliki hubungan timbal balik dan saling mempengaruhi serta masing-masing memiliki fungsi tersendiri terhadap anggota keluarga dan masyarakat. Apabila struktur sosial ini tidak berfungsi, struktrul sosial akan mengalami gangguan dan hilang dengan sendirinya. Begitu juga terhadap keluarga, apabila tidak mampu menjalankan fungsinya, maka keluarga itu akan mengalami goncangan dan kemudian hilang (disharmoni atau perpecahan). Dalam fungsionalisme terdapat anggapan dasar bahwa masyarakat (keluarga) haruslah dilihat sebagai bagian yang saling berhubungan satu dan lainnya; hubungan-hubungan itu dapat terjadi dalam hubungan asosiatif (terdiri dari kerjasama, akomodasi, dan asimilasi) dan disasiosiatif (terdiri dari persaingan, kontroversi, dan pertentangan) (Liliweri, 2005: 135-192).

Sementara itu Ihromi (1995) mengatakan, peran pokok perempuan dalam sebuah kebudayaan dibagi ke dalam tiga hal. Pertama, peran produktif yang menyangkut pendapatan demi kelangsungan hidup keluarga, tanpa perempuan harus mendapat gaji selayaknya, seperti bertani dan berdagang. Kedua, peran reproduksi, peran yang menyangkut kelangsungan hidup manusia dalam keluarga, seperti melahirkan; menyusui; memasak dan beberapa pekerjaan domestik lainnya. Ketiga, peran sosial, yakni peran yang terkait dengan hubungan komunal luar/ sosialisasi.

\section{Kajian Terdahulu}

Penelitian tentang perceraian telah dilakukan oleh beberapa lembaga 
maupun individu, berikut beberapa penelitian terdahulu, baik penelitian perceraian secara umum maupun cerai gugat secara khusus, antara lain yaitu, pertama, penelitian "Kemajuan terbaru dalam Perceraian di Indonesia: Idealisme perkembangan dan Pengaruh Perubahan Politik", penelitian dilakukan oleh M. Cammack, T. Heaton (2011), Heaton dalam kajian sebelumnya menyebutkan bahwa dinamika yang mendasari perubahan perilaku keluarga di Indonesia telah bergeser dari waktu ke waktu (Heaton et al., 2001). Tren perceraian di Indonesia pada abad ke-20 telah menarik perhatian masyarakat Barat. Sementara kekuatan-kekuatan sosial yang terkait dengan modernisasi menghasilkan kenaikan yang dramatis dalam masyarakat. Bukti terakhir menunjukkan bahwa tren perceraian telah berbalik arah di Indonesia dan tingkat perceraian sudah mulai meningkat. Kemungkinan faktor-faktor sosial tertentu telah menggeser tingkat perceraian seperti hubungan antara kekerabatan, kondisi ekonomi, tingkat pendidikan, tinggal di perkotaan/pedesaan, agama, dan usia di perkawinan. Secara khusus, pentingnya usia saat menikah sebagai prediktor stabilitas perkawinan, begitu juga factor pendidikan menjadi penting.

Hasil kuantitatif studi ini menunjukan, peningkatan angka perceraian dimulai pada akhir 1990-an dan awal 2000-an. Kenaikan perceraian terjadi pada spektrum yang luas di Indonesia. Sementara analisis kualitatif menunjukkan bahwa media dan meningkatnya penekanan pada hakhak perempuan telah memainkan peran penting dalam peningkatan perceraian. Temuan dari tulisan ini konsisten dengan gagasan bahwa keyakinan termasuk dalam 'perkembangan idealisme' dapat menjelaskan baik penurunan dan peningkatan berikutnya pada perceraian di Indonesia. Dampak social mempengaruhi perilaku keluarga, hal ini sering tergantung pada struktur yang sudah ada dan pengaturan ideologis terhadap mereka. Di konteks sistem awal perjodohan, peningkatan pendidikan memiliki efek mengurangi pengaruh orang tua terhadap kehidupan anak-anak mereka yang akhirnya menghasilkan pernikahan yang lebih stabil (Asian Journal of Social Science 39. 2011: 776796).

Kedua, penelitian tentang "Tinjauan Yuridis Penyebab Perceraian di Kota Palembang" oleh Wahyu Ernaningsih dan Tim dari Fakultas Hukum Universitas Sriwijaya, tahun 2009. Penelitian ini menggunakan metode yuridis empiris/ non doctrinal yang salah satu tujuannya adalah untuk menganalisis dan memberikan jawaban tentang keefektifan bekerjanya seluruh struktur institusional hokum. Data yang digunakan adalah data primer yang didapat dari sumber pertama meliputi aparat penegak hokum, masyarakat Kota Palembang dan aktivis perempuan Kota Palembang, serta data sekunder yang didapat melalui studi kepustakaan sebagai data pendukung. Tingkat perceraian di kota Palembang dalam kurun waktu lima tahun (2004-2008) cenderung bmengalami peningkatan dan $70 \%$ dari perkara cerai yang masuk di Pengadilan Agama Palembang adalah gugat cerai. Adapun factor penyebab gugat cearai adalah factor ekonomi, bias karena kemiskinan atau karena penghasilan istri lebih besar dari penghasilan suami; KDRT, poligami, keatidakadilan prinsip dan campur tangan keluarga. Ketidakadilan bagi perempuan yang akan menggugat cerai adalah masalah ekonomi, kutrangnya pengetahuan tentang proses perceraian dan factor budaya .

Berbeda dengan beberapa penelitian tersebut yang lebih menyoroti pada faktor-faktor penyebab perceraian, penelitian tren cerai gugat ini lebih fokus pada alasan dibalik keputusan perempuan 
melakukan cerai gugat. Penelitian ini juga ingin menggali sejauhmana sistem yang mempengaruhi perilaku individu dalam paradigma fungsionalismestruktural (struktur sosial, sistem sosial, kepribadian, dan organisme sosial) yang ada dalam masyarakat (keluarga) berfungsi/berkontribusi dibalik keputusan perempuan melakukan cerai gugat. Untuk itu penelitian ini juga akan mengkaji struktur sosial yang ada, di antaranya nilai-nilai dan norma (agama, filsafat, adat, sistem hukum), peran-peran lembaga sosial seperti BP4, penghulu (KUA), keluarga/kerabat, dan unsur lainnya dalam mencegah atau mendorong terjadinya cerai gugat.

\section{Metode Penelitian}

Metode penelitian yang digunakan adalah penelitian kualitatif dengan observasi dan wawancara sebagai metode utama pengumpulan data. Untuk wawancara, informan yang dilibatkan dalam penggalian data terdiri dari key informan yaitu istri (sebagai pelaku) yang telah melakukan cerai gugat sebanyak 2 (dua) orang. Selain key informan, beberapa pihak akan dijadikan sebagai narasumber, yaitu: suami sebagai pasangan yang dicerai dengan cerai gugat sebanyak 1 (satu) orang, unsur keluarga dekat yang mendampingi proses cerai gugat, tokoh masyarakat sebanyak 7 (tujuh) orang, tokoh agama sebanyak 1 (satu) orang, pejabat struktural Pengadilan Agama terdiri dari Hakim dan petugas mediasi yang mendampingi pasangan yang mengajukan perceraian (cerai gugat) sebanyak 2 (dua) orang, serta pejabat Kankemenag dan pejabat KUA/ penghulu yang sebelumnya menangani penasehatan/bimbingan perkawinan. sebanyak 6 (enam) orang dan Ormas perempuan sebanyak 2 (dua) orang

Untuk data pendukung, dihimpun melalui review berbagai buku, hasil penelitian, dokumen, dan laporan, baik dari institusi kementerian agama serta pemerintah daerah terkait objek penelitian. Sebagai key informan maka sebagai kriteria adalah mereka yang saat penelitian dilakukan dalam usia kritis perkawinan (1-5 tahun masa perkawinan) dan perceraian pada maksimal 3 tahun terakhir. Adapun kriteria narasumber adalah mereka yang mengetahui permasalahan seputar kehidupan terkait pasangan yang melakukan cerai gugat. Daerah yang akan diteliti adalah Kota Cilegon, karena dalam laporan Badilag MA (2014), ini merupakan daerah yang memiliki angka tinggi dalam kasus cerai gugat. Sedangkan waktu penelitian dilakukan pada bulan April 2015.

Setelah pengumpulan data melalui kajian di lapangan, akan dilakukan analisis data. Analisis data dimulai dengan menelaah seluruh data yang tersedia. Pendekatan yang digunakan dalam analisis data bersifat induktif, yaitu melalui reduksi data, pengelom, dan ketegorisasi data, dengan jalan abstraksi yang merupakan upaya memuat rangkuman inti, proses, dan pernyataan. Sebagai tahap akhir sebelum kesimpulan, dilakukan interpretasi, yaitu mencoba untuk memaknai, mendiskusikan, membandingkan, mencocokkan, dengan teori yang ada.

\section{Profil Kota Cilegon}

Kota Cilegon dikenal sebagai kota industri di kawasan Banten bagian barat dan merupakan pintu gerbang utama yang menghubungkan Pulau Jawa dengan Pulau Sumatera. Pada saat berdiri tahun 1999 Kota Cilegon terdiri dari 4 (empat) kecamatan 2 (dua) kelurahan dan 41 (empat puluh satu) desa. Dalam perkembangannya Kota Cilegon telah memperlihatkan kemajuan yang pesat di berbagai bidang baik bidang fisik maupun sosial ekonomi. Sehingga ada 
beberapa pertimbangan mengapa Cilegon menjadi sasaran (investasi). Mulai dari geografis, letak wilayah Cilegon maupun mekanisme perizinan yang lebih dipercepat. (Prawira, Wawancara, 29/2/2016).

Berdasarkan Peraturan Daerah nomor 15 tahun 2002 dan Peraturan Daerah nomor 12 tahun 2003 struktur administrasi wilayah Kota Cilegon mengalami pemekaran menjadi 8 (delapan) kecamatan dan 43 (empat puluh tiga) kelurahan. Luas wilayah Kota Cilegon terdiri dari daratan seluas 175,51 $\mathrm{km}^{2}$, termasuk 5 (lima) pulau yaitu pulau Merak Besar, Merak Kecil, Pulorida, Tempurung, dan Pulau Ular.

\begin{tabular}{|c|c|c|}
\hline & geografis & Kot \\
\hline rbatasan & dengan & \\
\hline
\end{tabular}
disebelah barat dan Kabupaten Serang di utara, timur, dan selatan. Kota Cilegon merupakan Kota yang paling sedikit jumlah penduduknya di Provinsi Banten. Menurut hasil pencacahan lengkap Sensus Penduduk (SP) 1990 penduduk Kota Cilegon berjumlah 226,1 ribu jiwa, dan dari hasil SP2000, jumlah penduduk Kota Cilegon sebesar 294,9 ribu jiwa. Pada bulan Mei 2010 dilakukan Sensus Penduduk 2010 (SP2010). Dari hasil akhir SP2010 jumlah penduduk Kota Cilegon tercatat sebesar 373,4 ribu jiwa. Selang periode tahun 2010-2013, jumlah penduduk bertambah menjadi 398,3 ribu jiwa dengan laju pertumbuhan penduduk sebesar 1,9 persen per tahun.
Penduduk laki-laki di Kota Cilegon sedikit lebih banyak daripada perempuan. Jumlah penduduk Kota Cilegon yang berjenis kelamin laki-laki berjumlah sekitar 203,5 ribu jiwa dan penduduk perempuan sebesar 194,8 ribu jiwa. Dengan demikian sex rasio penduduk Kota Cilegon sebesar 104. Kecamatan Citangkil merupakan kecamatan dengan jumlah penduduk terbanyak, yaitu mencapai 69,9 ribu jiwa. Sedangkan, kecamatan paling sedikit penduduknya adalah Kecamatan Purwakarta yang berjumlah 39,4 ribu jiwa.

Proporsi penduduk laki-laki terbanyak terdapat di Kecamatan Purwakarta dan Ciwandan dengan sex rasio sebesar 107. Dilihat dari perkembangannya, Kecamatan Cibeber, Grogol, dan Citangkil adalah tiga kecamatan dengan tingkat pertumbuhan penduduk yang cukup pesat, yaitu masing-masing sebesar 2,92 persen, 1,99 persen dan 1,89 persen per tahun. Hal ini dimungkinkan karena banyaknya pengembangan perumahan di ketiga kecamatan tersebut. Sedangkan wilayah terpadat penduduknya adalah Kecamatan Jombang dengan tingkat kepadatan mencapai 5.534 penduduk per kilometer persegi. Diikuti Kecamatan Cilegon dengan 4.595 jiwa/Km2.

Jika dilihat dari prosentase pemeluk agama di Kota Cilegon pada tahun 2013, maka dapat dilihat dalam tabel berikut ini: 
Persentase Pemeluk Agama

Menurut Kecamatan di Kota Cilegon

Tahun 2013

\begin{tabular}{|c|c|c|c|c|c|c|c|c|}
\hline \multirow[t]{2}{*}{ No } & \multirow[t]{2}{*}{ Kecamatan } & \multicolumn{6}{|c|}{ Agama } & \multirow[b]{2}{*}{ Jumlah } \\
\hline & & Islam & Kristen & Katholik & Hindu & Buddha & Konghucu & \\
\hline 1 & Ciwandan & 99,51 & 0,23 & 0,15 & 0,09 & 0,02 & 0,00 & 100 \\
\hline 2 & Citangkil & 97,09 & 2,22 & 0,60 & 0,05 & 0,04 & 0,00 & 100 \\
\hline 3 & Pulomerak & 97,97 & 1,44 & 0,03 & 0,45 & 0,12 & 0,00 & 100 \\
\hline 4 & Purwakarta & 97,20 & 1,78 & 0,33 & 0,52 & 0,16 & 0,00 & 100 \\
\hline 5 & Grogol & 99,10 & 0,68 & 0,09 & 0,07 & 0,05 & 0,00 & 100 \\
\hline 6 & Cilegon & 97,32 & 1,73 & 0,13 & 0,63 & 0,21 & 0,00 & 100 \\
\hline 7 & Jombang & 95,61 & 1,22 & 2,12 & 0,33 & 0,72 & 0,00 & 100 \\
\hline 8 & Cibeber & 97,64 & 2,17 & 0,06 & 0,06 & 0,06 & 0,00 & 100 \\
\hline \multicolumn{2}{|c|}{ Kota Cilegon } & 97,68 & 1,42 & 0,44 & 0,28 & 0,17 & 0,00 & 100 \\
\hline
\end{tabular}

Data BPS Kota Cilegon 2014

Dari data di atas sebagian besarnya adalah pemeluk agama Islam yang tersebar merata di delapan kecamatan. Penganut Katholik mayoritas berada di kecamatan Jombang dan Citangkil, pemeluk agama Hindu mayoritas berada di Kecamatan Cilegon dan Purwakarta, dan pemeluk agama Buddha mayoritas berada di Kecamatan Jombang dan Cilegon.
Orang beragama biasanya mempunyai tempat untuk melaksanakan ritual yang diyakini, sarana peribadatan di Kota Cilegon masih 100\% didominasi oleh penduduk mayoritas yaitu Islam. Lebih lanjut mengenai jumlah tempat ibadat dapat dilihat pada tabel berikut ini:

Jumlah Tempat Peribadatan

Menurut Jenisnya di Kota Cilegon Tahun 2013

\begin{tabular}{|c|c|c|c|c|c|c|c|}
\hline No & Kecamatan & Masjid & Mushalla & Langgar & Gereja & Vihara & Jumlah \\
\hline 1 & Ciwandan & 64 & 5 & 66 & - & - & 135 \\
\hline 2 & Citangkil & 68 & 89 & 79 & - & - & 236 \\
\hline 3 & Pulomerak & 48 & 29 & 17 & - & - & 94 \\
\hline 4 & Purwakarta & 38 & 3 & 33 & - & - & 74 \\
\hline 5 & Grogol & 38 & 7 & 42 & - & - & 87 \\
\hline 6 & Cilegon & 40 & 17 & 7 & - & - & 64 \\
\hline 7 & Jombang & 58 & 36 & 44 & - & - & 136 \\
\hline 8 & Cibeber & 37 & 36 & 22 & - & - & 95 \\
\hline & Jumlah & 391 & 222 & 310 & - & - & 923 \\
\hline
\end{tabular}

Data Statistik Kota Cilegon 2014 


\section{Temuan dan Pembahasan}

\section{A. Gambaran 3 Kasus Cerai Gugat}

\section{Pasangan SM (Istri) dan Yd (Suami).}

\section{Masa Pra Nikah}

SM umur 34 tahun, pendidikan SLTA, agama Islam, pekerjaan mengurus rumah tangga, tempat tinggal di Jalan Ir. Sutami Link. Kapudenok Masjid, Rt. 01, Rw. 01, No. 14, Kelurahan Lebakdenok, Kecamatan Citangkil, Kota Cilegon.

Pada awal pernikahan SM merasa sudah siap lahir batin untuk lillahi ta'ala dalam hidup berumah tangga. Ia akan berusaha menjadi istri yang sholehah dan terbaik bagi suami, karena calon suami juga atas pilihannya sendiri. SM memilih Yd sebagai suami, karena selama pacaran sekitar 1 tahun, dia bersikap baik dan perhatian. Ketika Yd sedang mempunyai uang maka selalu mengajak makan di luar dan jalan-jalan ke mall. Ketika ibunya sakit, juga membantu biaya pengobatannya.

Sebelum menikah SM belum bekerja, namun Yd sudah bekerja honorer di Kementerian Agama RI. Walaupun SM belum mempunyai penghasilan, namun ia merasa sudah siap lahir batin, karena menurut prinsipnya untuk masalah uang bisa dicari berdua setelah menikah.

Untuk meningkatkan hubungan dilakukan prosesi lamaran di rumah SM yang diterima oleh ibu dan saudarasaudaranya. Dari pihak Yd, ikut hadir adalah kedua orang tua dan 2 kakaknya, karena ia adalah anak bungsu dari 3 bersaudara. Keluarga Yd datang dengan membawa buah-buahan dan kueh, diantaranya kueh putu dan papais. Pada saat lamaran disepakati juga tentang waktu pelaksanaan akad nikah berdasarkan perhitungan orang tua.

Sekitar satu bulan setelah lamaran, berdasarkan perhitungan orang tua, dilanjutkan akad nikah pada tanggal 28 Desember 2007. (Kutipan Akta Nikah No.829/64/XII/2007).Akad nikah dilaksanakan di rumah SM dan dilanjutkan dengan resepsi kecilkecilan. Setelah itu dilanjutkan dengan serah terima pengantin oleh perwakilan masing-masing mempelai. Dilanjutkan dengan saweran, yalil dan bersalaman dengan para undangan yang hadir untuk mengucapkan selamat kepada mempelai. Setelah akad nikah, hati SM merasa gembira, karena dapat menikah dengan laki-laki pilihannya.

Menurut pengakuan Sh dan As -ibu dan kakak kandung SM- agak kurang setuju menikah dengan Yd, karena menurut informasi yang diterima mereka, ia suka minum-minuman keras, namun karena kemauan SM sudah bulat, sebagai orang tua dan saudara-saudaranya hanya mendoakan semoga menjadi keluarga yang baik. Pada prosesi akad nikah sebagian besar dana adalah dari keluarga $\mathrm{SM}$, hanya sebagian kecil bantuan dari pihak keluarga Yd.

\section{Masa Pernikahan}

Setelah akad nikah di rumah SM, mempelai tinggal di rumah orang tua $\mathrm{SM}$ selama 3 hari. Semasa mempelai menjalani masa bulan madu di rumah orang tua SW dijalani sebagaimana pengatin baru, semua kebutuhan hidup selama 3 hari tersebut disiapkan oleh keluarga SM. Setelah tiga hari di rumah mertua, kemudian mempelai di boyong ke rumah orang tua Yd. Pada awalnya SM menghendaki untuk tinggal di kontrakan, namun mertua perempuan tidak berkenan kalau mempelai tinggal di luar rumah sehingga SM "terpaksa" memenuhi kehendak mertuanya.

Setelah tinggal di rumah mertua, SM merasa seperti tinggal di sangkar burung emas. Pekerjaan sehari-hari di rumah mertua adalah mandi, makan dan melayani suami, karena sudah ada

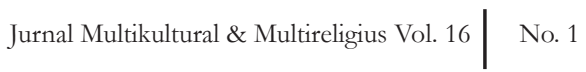


2 pembantu rumah tangga di rumah mertua yang mengerjakan pekerjaan rumah tangga. Namun demikian SM tidak merasa nyaman tinggal di rumah mertua, karena semenjak tinggal di rumah mertua, tingkah Yd berubah $180^{\circ}$. Sisa dana walimahan yang sedianya ditabung, justru digunakan oleh Yd untuk modifikasi "motor ninja" miliknya, sehingga menimbulkan percekcokan.

Kemudian ketika Yd menerima uang honor, SM hanya dikasih sebagian, bahkan terkadang tidak diberi uang oleh Yd. Menurut pengakuan SM, selama menikah dengan Yd, ia tidak pernah tahu berapa gaji honornya. Baju yang yang dia pakai hanya baju-baju yang dibawa dari rumah orang tuanya, sehingga baju yang dipakai sehari-hari kelihatan lusuh.

Antara SM dan Yd jarang berkomunikasi, karena setelah pulang kerja Yd biasanya main bersama kawankawannya dan pulang pada pagi hari. Ketika dikonfirmasi tentang kegiatannya di luar, seringnya marah-marah, bahkan menurut pengakuannya pernah hampir di cekik. Dari kebiasaannya yang sudah mulai kelihatann aslinya, Yd akan bertingkah agak baik ketika ada maunya, namun tidak jarang ia juga memaksa ketika ingin berhubungan suami istri. Dengan keadaan yang demikian, SM pernah menanyakan kepada Yd, "tujuannya apa sih menikah dengan saya", jawab Yd "hanya ingin merasakan barangmu". Begitu terkejutnya SM mendengar jawaban Yd, sehingga ia merasa bingung. Mau bercerita kepada siapa, tidak ada yang bisa diajak bicara, karena setelah tinggal di rumah mertua, ia juga tidak memegang HP.

Dalam kesehariannya SM jarang berkomunikasi dengan mertua, karena seringnya berada di kamar, hanya sekalikali ngobrol dengan mertua. Dengan Yd juga jarang-jarang bisa berkomunikasi sehingga menambah rumit persoalanya. Ketika sedang terjadi perselisihan antara
Yd dan SM tidak jarang ibu mertua ikut terlibat dan membela Yd. Ketika terjadi perselisihan Yd terkadang tidak segansegan memukul dan menendang.

Dengan seringnya terjadi pertengkaran dengan sebab-sebab masalah nafkah, komunikasi yang hanya searah, serta beberapa keinginan Yd yang tidak terpenuhi menambah beban mental SM sehari-hari. Namun harapan SM masih ada, sehingga ia berharap Yd bisa berubah. Walaupun berbagai perselisihan telah terjadi namun sampai SM mempunyai anak pertama, biduk rumah tangganya masih bisa dipertahankan. Bahkan Yd pernah menyampaikan ke SM, bahwa anak yang dilhirkan bukan anaknya.

Setelah anak pertama lahir, persoalan bukannya berkurang namun bertambah lagi. Persoalan nafkah yang belum terselesaikan, campur tangan mertua perempuan, dan memaksa berhubungan sexual walaupun SM sedang tidak berkehendah. Menambah beban berat kehidupan SM di sangkar emas mertua.

Karena berlarut-larutnya persaoalan dalam rumah tangga SM dan Yd, tanpa ada solusi akhirnya timbul keinginan SM untuk menggugat cerai Yd. Namun setelah SM berbicara dengan Yd tidak ada tanggapan yang bisa menenangkannya. Bahkan SM dipersilahkan untuk menggugat namun Yd tidak akan mengeluarkan biaya untuk proses gugat cerai tersebut. Karena sudah sama-sama tidak mau hidup berumah tangga, maka akhirnya SM mengguat Yd ke PA Cilegon.

\section{Tahap Gugatan Cerai}

Proses gugatan cerai sendiri tidak berlangsung lama. Ketika akan ke PA cilegon, keluarga SM sempat memberi nasihat agar diurungkan, namun dengan 
penjelasan SM beberapa kejadian yang menimpanya, maka pihak keluarganya menyerahkan sepenuhnya kepada SM. Pada mulanya SM sesungguhnya merasa berat karena sudah mempunyai satu anak, namun karena SM merasa sudah tidak kuat lagi bersama Yd, maka dikukuhkannya untuk mengajukan CG ke PA Cilegon.

Pada saat sidang pertama di PA Cilegon, Yd tidak menghadiri, sehingga tidak ada proses mediasi anatara SM dan Yd. Begitupun pada sat sidang ke dua Yd tidak hadir, sehingga dalam proses CG SM merasa tidak ada hambatan yang berarti. Selama proses sidang, SM ditemani pihak ibu dan kakak. Dengan tidak hadirnya Yd di sidang pengadilan, kelihatnnya membuat keputusan hakim menjadi lebih cepat.

\section{Pasca Gugatan Cerai}

Ketika hakim mengabulkan CG yang dijukan SM, maka ia merasa gembira bisa terlepas dari sangkar burung emas Yd. Setelah surat kuning turun SM tinggal di rumah orang tua bersama anaknya. Ketika peneliti mengunjungi rumah $\mathrm{SM}$, ada kesempatan berdialog dengan anaknya yang sudah berumur 5 tahun. Peneliti menanyakan tentang bapaknya, ia diam saja dan ketika diajak ke rumah Yd, ia tidak mau. Dari wajah sang anak ketika ditanyakan tentang bapaknya, terlihat tidak ada eksprsi gembira dan justru cenderung menutup mukanya ke pelukan ibu ataupun neneknya.

\section{Pasangan SS (Istri) dan HS (Suami)}

\section{Masa Pra Nikah}

SS umur 28 tahun, pendidikan D3, agama Islam, pekerjaan karyawan swasta, tempat kediaman di Komp. Perumnas Bumi Cibeber Kencana (BCK) Blok C.2
Rt. 04 Rw. 10, No. 13 Kelurahan Cibeber, Kecamatan Cibeber Kota Cilegon.

Menurut SS, menikah adalah proses sakral yang dilakukan sekali dalam seumur hidupnya, dengan tujuan membuat hati tenang serta membina hidup rumah tangga yang bahagia. Pada awal mau menikah dengan (HS), SS kurang sreg karena belum begitu mengenalnya. Namun karena orang tua SS sudah setuju sehingga pernikahan dapat terus dilaksanakan. Pada awalnya SS pernah meminta kepada orang tua untuk membatalkan pernikahannya, karena ada hal-hal yang kurang disukai oleh SS. Oleh karena itu SS berpikir ulang untuk dijalani dahulu dalam pernikahan tersebut.

Ketika wawancara dengan orang tua SS, mereka menceritakan bahwa HS bekerja satu perusahaaan dengan ibu SS, sehingga sedikit tahu tentang HS. Oleh karena itu setelah mengetahui bahwa SS berpacaran dengan HS orang tua cenderung menyetujuinya, walaupun secara jujur orang tua SS belum begitu mengenal HS.

SS dalam berpacaran dengan HS sekitar 2 bulan, itupun jarang bisa berkomunikasi secara baik, karena masing-masing bekerja secara shif di perusahaan, sehingga jarang sekali bisa berkomunikasi secara langsung. Dengan singkatnya pertemuan antara SS dan HS dan jarangnya berkomunikasi langsung antara mereka sehingga antara mereka belum begitu saling mengenal.

Pada dasarnya menurut SS, ia sudah siap lahir dan batin untuk menikah. Pada saat mau menikah ia sudah mempersiapkan diri dengan bekal ilmu agama. Ia juga sudah mengenakan jilbab sebelum menikah. Menurut SS, harta dapat dicari berdua, sehingga masalah ekonomi sejak awal pernikahannya tidak dipermasalahkan.

Jurnal Multikultural \& Multireligius Vol. 16 $\mid$ No. 


\section{Masa Pernikahan}

Pada saat pernikahan, SS sudah berdandan secara rapi dan berusaha tersenyum, namun menurut temantemannya kelihatan cemberut. Ia merasa belum sreg betul menikah dengan calon suaminya, sehingga walaupun ia sudah berusaha menyiapkan diri raut mukanya masih kelihatan cemberut. Dalam pesta pernikahan tersebut pihak kelurga SM memberikan sumbangan sebesar 15 juta. Uang sebesar itu menurut SS sesungguhnya masih kurang karena pernikahan tersebut dilaksanakan di Kota Cilegon. Menurut SS, mungkin karena SM berasal dari daerah sehingga menganggap bahwa dengan jumlah uang tersebut mencukupi, namun ia tidak mempermasalahkan jumlah uang tersebut.

Setelah menikah mereka tinggal di Komp. Citra Garden BMW berpisah dengan orang tua. Pada awal kehidupan rumahtangganya berjalan sepertikeluarga pada umumnya, namun kemudian SS merasa mulai ada yang aneh dalam kehidupan rumah tangganya. Ketika SS menghendaki memiliki momongan HS belum mau, alasannya belum siap secara finansial. Namun SS merasa kalau suami sedang bekerja, ia merasa sendirian dan kesepian di rumah sehingga ingin memiliki anak. Dengan berbagai usaha selama ini akhirnya setelah 10 bulan pernikahannya bisa hamil, namun menurut SS suaminya kurang begitu senang dengan kehamilannya.

Mengenai keuangan, SSjuga melihat HS tidak transparan. Terutama mengenai penghsilannya, baik gaji maupun bonusbonusnya. SS pernah menanyakan gaji suami namun justru terjadi perselisihan. HS juga seorang yang pendiam, baik di rumah maupun di kantor. Ketika sedang berada di rumah kalau tidak ditanya, tidak ada komunikasi, kalaupun dijawab sangat singkat. Begitupun di kantor, ketika SS menanyakan kepada kawannya di kantor juga menyebutkan bahwa HS adalah seorang yang pendiam.

Ketika HS ditanyakan kenapa diam saja, HS tidak menjawab. Dengan kondisi HS yang cenderung diam kalau diajak berkomunikasi SS merasa tertekan. Ia mempertanyakan dirinya sendiri, "bagaimana ke depan kalau tidak mau mengobrol sama sekali, kalau saya ada masalah dipendam sendiri dan diselesaiakan sendiri. Hidup dengan gaji saya sendiri".

Tentang persoalan sexual, dalam beberapa tahun terakhir HS juga jarang melakukannya. SS pernah curhat kepada saudara HS tentang persoalan sexual, saudaranya justru menanyakan "kenapa suami yang tidak mengajak duluan?" SS menjawab, "kalau saya mengajak, tangan saya ditepis, kalau HS dipelukjuga tidakmau", sehingga SS merasa bahwa sekan-akan dia bukan istrinya. SS waktu itu khawatir, kalau ia tidak mengajak berhubungan HS maka mungkin akan pindah ke yang lain.

Pada awal pernikahan SS dan HS sebagaimana hubungan suami istri pada umumnya melakukan hubungan sexual, walaupun SS yang selalu mendahului mangajaknya. Namun pada beberapa tahun terakhir HS jarang sekali melakukan hubungan sexual, bisa 4-5 bulan sekali. Ketika mediasi di PA, hal tersebut juga sempat ditanyakan mediator kata HS, "karena ada anak". Selanjutnya mediator memberi jawaban, "anak ko jadi alasan".

Setelah mempunyai anak, HS sepertinya merasa keenakan, enjoy dengan dirinya sendiri dan kurang memperhatikan kebutuhan keluarga, untuk makan sehari-hari menggunakan uang istri. Kalau HS ditanya tentang gaji dan bonus justru terjadi percekcokan. Menurut SS, asalkan transparan dalam membagi-bagi keuangan untuk keluarga dan anak tidak menjadi persoalan, sampai sekarangpun akan dipertahankan keluarganya. Namun karena tidak transparan, tidak ada komunikasi yang 
baik dalam kehidupan keluarga sehingga SS memberanikan diri untuk mengajukan ke PA.

\section{Tahap Gugatan Cerai}

Dalam proses pengajuan cerai, SS sudah dua kali mengajukan ke PA. Pengajuan yang pertama baru sampai pendaftaran di PA, kemudian dicabut kembali, karena dinasehatin orang tua agar dikomunikasikan lagi, karena hanya masalah ekonomi. Sebab menurut orang tuanya itu masalah sepele yang masih dapat diperbaiki, padahal menurut SS sesungguhnya permasalahan tersebut sudah memberatkannya.

Setelah SS berdamai dengan suami, dua minggu pertama kelihatan harmonis, namun pada minggu berikutnya persoalan-persoalan dalam rumah tangganya muncul kembali hingga berlarut-larut tanpa ada penyelesaian. Ketika SS berkomunikasi dengan suami untuk sama-sama menyelesaikan permasalahnnya, HS diam saja. Akhirnya SS mendaftarkan gugatannya ke PA yang ke dua.

Pada waktu sidang di PA, sempat terjadi mediasi, namun HS tidak dapat mengkomunikasikan persoalan-persoalan yang menjadi beban penggugat, baik dengan SS maupun dengan orang tuanya. Persoalan yang perlu dikomunikasikan pada kasus SS dan SM antara lain, masalah nafkah, dan hubungan sexual. Terkait masalah nafkah, HS seringkali lupa dengan tanggung jawab anak dan istrinya. Menurut pengakuan ibu SS, ketika jumlah uang di ATM HS hanya cukup untuk membayar rumah, maka akan diberikan ke istri, namun ketika ATM dipegang SS, herannya HS selalu cemberut. Bahkan karena persoalan ekonomi SS pernah ditendang kepanya oleh HS di depan orang tuanya.
Pada pengajuan yang kedua keluarga SS berupaya melindungi anak semata wayangnya, karena telah mengetahui persoalan yang sesungguhnya dan melihat dengan jelas kelakuan HS. Selanjutnya orang tua SS hanya menyerahkan persoalan gugatan tersebut ke SS.

\section{Pasca Gugatan Cerai}

Setelah surat gugatan SS dikabulkan oleh hakim PA Cilegon, SS dan anaknya tinggal bersama kedua orang tuanya. Menurut kedua orang tua SS, setelah gugatan anaknya diputuskan, mantan suami masih merasa tidak bersalah, bahkan kedua orang tua SS merasa heran dengan ketidakpahamannya tersebut.

\section{Pasangan SL (Istri) dan AK (suami).}

\section{Masa Pra Nikah}

SL berumur 25 tahun, pendidikan S1, Agama Islam, pekerjaan mengurus Rumah Tangga, tempat kediaman di Link. Tegal Padang, Rt. 03, Rw. 03, Kelurahan Kebondalem Kecamatan Purwakarta Kota Cilegon.

Ia punya prinsip tidak mau berpacaran. Menikah merupakan ibadah sehingga setelah mengenal AK selama sekitar 4 bulan kemudian menikah. Selama proses perkenalan tersebut, ia sesungguhnya belum begitu mengenal kepribadianya, namun karena dorongannya yang kuat akhirnya SL dan AK menikah.

SL menikah dengan AK atas keinginannya sendiri. Sebelum menikah SL pernah dinasihati oleh temannya ketika meminta respon terhadap calon suaminya walaupun temannya belum pernah bertemu dengan AK, agar SL bersabar dengan kondisi calon suaminya. Karena menurut perhitungannya, AK mempunyai watak yang keras.

Jurnal Multikultural \& Multireligius Vol. 16 $\mid$ No.1 
Menurut Sy (ibu SL) pada awal mengenal AK "seperti orang bener", Sy juga merasa "seperti ragu-ragu mau menikahkan anaknya dengan SL, karena kelihatannya tidak serius" namun dengan meyakinkan, SL dapat menenangkan keragu-raguan para pihak yang kurang yakin terhadap keseriusan SL untuk menikah dengan AK. Dengan keyakinan tersebut SL berharap bahwa AK adalah suami pertama dan terakhir baginya. AK bekerja di PT Satomer Cilegon sebagai pegawai kontrak.

\section{Masa Pernikahan}

Setelah menikah dengan SL, mereka tinggal di rumah orang tuanya. Namun semenjak menikah dalam keseharian AK mulai terlihat watak aslinya yang keras. Selama hidup berumah tangga SL tidak pernah tahu berapa jumlah gaji suaminya. Ketika AK mendapatkan gaji, paling banyak diberikan kepada istri hanya satu juta dan selanjutnya hanya sekitar 200-300 ribu sebulan. Ketika AK dikonfirmasi tentang penghasilannya untuk apa saja, kemudian berakhir dengan pertengakaran.

Sehari menginap di rumah mertua, dua hari AK menginap di rumah orang tuanya. Kadang dua hari menginap di rumah mertua, 4 hari menginap di rumah orang tua. Dengan keadaan demikian, SL menyarankan ke AK untuk mengontrak agar keluarga lebih mandiri, namun AK selalu menolaknya.

Hari demi hari menurut SL selalu ada permasalahan dalam kehidupan rumah tangganya yang tidak bisa diselesaikan. Bahkan dengan hal-hal kecil misalnya ingin berangkat kondangan bersama suami ke rumah saudara selalu diwali dengan perselisihan. Tentang sholat dan puasa wajib juga selalu diingatkan yang terkadang ujung-ujungnya terjadi pertengakaran. Pernah satu saat puasa ramadhan di rumah sudah sahur, namun di rumah kakaknya ternyata makan siang, hal ini sudah beberapa kali terjadi. Walaupun demikian SL masih bisa bertahan dengan kondisi tersebut.

Hingga 2 kali mediasi di rumah kakak ipar masih bisa berusaha mempertahankan perkawinannya. Yang unik menurut SL semenjak mediasi yang pertama sesungguhnya kakak ipar sudah mendorong SL untuk mengggugat ke PA, namun ia masih bertahan. Hingga setelah mediasi yang ke dua SL sudah merasa tidak mampu lagi untuk bisa mempertahankan biduk rumah tangganya, sehingga mengungkapkan kepada AK "yang mengajukan saya atau $A K^{\prime \prime}$, namun suami justru menyerahkan kepada SL untuk mengurus gugat cerainya dengan alasan tidak mempunyai biaya.

\section{Tahap Gugatan Cerai}

Kemudian SL mengajukan CG ke PA Cilegon dengan diantar saudara iparnya. Seperti sudah menjadi jalannya, proses pendaftaran dan sidang berjalan dengan lancar. Bahkan pada waktu akan sidang pertama AK juga dihubungi untuk bisa hadir dalam proses sidang, namun ternyata tidak bisa hadir begitupun dengan sidang ke dua tidak bisa hadir juga.

Sebagai penggugat, pada sidang pertama dan kedua SL membawa 2 saksi dari pihak keluarga yang mengetahui duduk persoalannya. Sehingga mereka bisamenjelaskankepadahakimbagaimana persoalan sesungguhnya yang terjadi dengan keluarga SL. Tidak ada mediasi dalam proses perceraian SL, karena AK tidak hadir dalam 2 persidangan. Karena tidak ada kehadiran pihak tergugat, baik sidang pertama maupun ke dua, maka hakim mengabulkan gugatan SL. 


\section{Pasca Gugatan Cerai}

SL merasa gembira setelah hakim mengabulkan permohonan gugatnya. Namun dengan dikabulkannya gugatan tersebut, AK beberapa kali mengintimidasi lewat pesan SMS hingga sekitar dua bulanan. Karena dirasa sampai mengganggu probadi SL, maka ia meminta bantuan kakak iparnya untuk membantu menghentikan intimidasi tersebut dan berhasil menyelesaikannya.

\section{B. Fenomena perceraian yang terjadi di Kota Cilegon}

Penulis menyadari, fenomena alasan perceraian yang terjadi di Kota Cilegon bukan alasan baru tetapi di saatsaat tersebut dibaca lewat paradigma sosiologi, fenomena ini sangat menarik untuk diteliti lebih lanjut. Perubahan sosial budaya bukanlah suatu gejala yang berdiri sendiri, tetapi selalu dipengaruhi oleh faktor-faktor tertentu. Terdapat dua faktor pendorong terjadinya perubahan sosial dan kebudayaan. Kedua faktor itu adalah faktor pendorong yang datangnya dari luar masyarakat (ekstern) dan faktor intern (dari mayarakat yang mengalami perubahan)

Keluarga, dalam hal ini suami istri seringkali berhadapan dengan perbedaan emosi, yang sewaktu-waktu berdampak positif ataupun negatif bagi keduanya. dalam situasi negatiflah keluarga akan mengalami guncangan, dan tidak sedikit dari mereka yang mengarah pada retaknya hubungan dan berakhir dengan perceraian.

Hidup berkeluarga tidak hanya mengandalkan cinta yang "abstrak" tetapi bagaimana membangun eksistensi keluarga dalam masyarakat dengan tidak menafikan unsur-unsur di luar cinta seperti: harta kekayaan, anak, hiburan, hubungan yang harmonis dan lain-lain. Sehingga yang terpenting dari dasar keluarga adalah bagaimana membangun relasi mutualistik antara suami dan istri yang dibungkus dengan cinta dan kasih sayang, sebagaimana tertuang dalam teori pertukaran, bahwasannya perkawinan perlu adanya jalinan pertukaran hak dan kewajiban antara suami-istri sehingga pada kondisi tertentu, dalam hal ini dapat memperkecil ruang perbedaan, dan memberikan ruang kesadaran kelebihan dan kekurangan yang dimiliki keduanya.

Sesuatu yang paling banyak dirasakan oleh pasangan dalam perkawinan adalah saat timbulnya ketidakpuasan dalam menjalani hidup bersama untuk membina keluarga. dengan menempuh jalan hidup masingmsaing dengan berbagai macam perkembangan dan motivasi untuk menciptakan kehidupan yang lebih baik.

Menurut Sohari, salah satu ulama di Kota Cilegon mengatakan bahwa, berdasarkan fenomena yang terjadi di masyarakat, terdapat banyak faktor yang dapat menimbulkan terjadinya perceraian, faktor pemicu munculnya perceraian dalam institusi keluarga lebih dominan disebabkan lemahnya pendidikan masyarakat. Di samping itu terdapat faktor lain yang paling sering menimbulkan perceraian adalah faktor ekonomi keluarga. (Sohari, wawancara, 24/05/2015)

\section{Proses di PA yang Singkat}

Sesudah pembacaan surat dan anjuran damai tidak berhasil, ketua majelis akan menanyakan kepada tergugat, apakah ia akan menjawab lisan atau tulisan. Namun dalam 3 kasus CG di atas, hanya 1 kasus yang mengalami tahapan replik-duplik yaitu kasus SM dengan Yd. Sejak saat itu, masuklah proses ke dalam tahap jawab menjawab, baik antara pihak dengan pihak maupun antara hakim dengan para pihak. 
Untukkasus Yd ternyata juga tidak dapat diselesaikan dengan mediasi walaupun hakim sudah menyediakan hak dan bebas serta leluasa untuk membela hak dan kepentinganya atas gugatan SM. Menurut ketua PA Kota Cilegon, kepada penggugat sesungguhnya diberi pula hak untuk menanggapi pembelaan tergugat, maka terjadilah dalam pemerikasaan persidangan suatu dialog langsung dalam bentuk replik duplik. Namun jawaban Yd tidak bisa meyakinkan hakim sehingga keputusan hakim untuk mengabulkan gugatan SM terpenuhi.

Lain halnya kasus SS dan SL pihak tergugat tidak mau menghadiri sidang pemeriksaan sekalipun sudah dipanggil secara patut dan resmi. Dalam hal seperti itu, Undang-undang memberi pengeculian. Hakim dapat menyelesaiakn perkara melalui proses Verstek sesuai dengan ketentuan pasal 125 HIR (Herzien Inlandsch Reglement) atau pasal 149 RBG (Reglement Buitengewesten). Pemeriksaan dan putusan dapat dilakukan hakim tanpa hadirnya tergugat. Atau jika salah satu pihak tidak mau hadir mengikuti pemerikasaan selanjutnya sekalipun sudah resmi diberi tahu tanggal pemunduran sidang yang akan datang. Seperti kasus SL, sudah memberitahukan kepada $\mathrm{AD}$ tentang proses tersebut namun AD tidak mau hadir. Dengan ketidak hadiran tanpa alasan yang sah, pemeriksaan tetap dilanjutkan hakim. Pemeriksaan seperti itu tetap dianggap bersifat contradictoir (tatacara pemeriksaan perkara mesti dilakukan jawab menjawab secara timbal balik). Sekalipun tanpa jawaban atau bantahan dari pihak yang tidak hadir, hal itu seperti dalam ketentuan pasal 127 HIR atau pasal 151 RGB.

Dalam kasus yang seperti SL dan SS pemeriksaan perkara tidak perlu diundur. Dapat tetap dilanjutkan walaupun pihak lawan tidak hadir. Karena dalam hal seperti itu, pihak yang tidak hadir dianggap pihak sungguh-sungguh tidak lagi membela kepentingannya dalam perkara yang bersangkutan. Dia dianggap sudah menerima apa saja yang dikemukakan pihak lawan.

\section{Penyebab Istri Menggugat Cerai Suami}

Di dalam sebuah perceraian sering kita jumpai banyak faktor-faktor atau penyebab terjadinya perceraian itu sendiri. Menurut data PA Kota Cilegon dari tahun 2011-2013, tiga penyebab tertinggi terjadinya perceraian dapat dilihat sebagi berikut:

\section{Penyebab Tertinggi Terjadinya Perceraian di PA Kota Cilegon Tahun 2011-2013}

\begin{tabular}{|c|c:c:c:c} 
No & \begin{tabular}{c} 
Penyebab Perceraian \\
\hdashline 1
\end{tabular} & 2011 & 2012 & 2013 \\
\hdashline 2 & Ekonomi & 79 & 115 & 250 \\
\hdashline 3 & $\begin{array}{c}\text { Tidak Harmonis } \\
\text { Tidak Ada Tanggung } \\
\text { Jawab }\end{array}$ & 149 & 169 & 98 \\
\hline
\end{tabular}

Setelah melihat data PA Kota Cilegon, faktorekonomimendudukiposisi tertinggi mengenai penyebab terjadinya perceraian, kemudian tidak harmonis dan menyusul tidak adanya tanggung jawab. Berdasarkan hasil wawancara dengan SM, Yd, SK, dan SL, dapat ditemukan beberapa sebab yang melatarbelakangi terjadinya cerai gugat di antaranya: adanya nusyus (durhaka), yaitu sikap tak acuh baik yang dilakukan oleh suami terhadap istrinya atau sikap istrinya terhadap suaminya, yang semuanya (suami-istri) tidak lagi mengindahkan antara kewajiban dan hak masingmasing; suami tidak pandai mengambil itibar dari latar belakang kehidupan istri sebelum mempersuntingnya padahal, pemberian nafkah yang berlatar belakang kaya seharusnya tidak sama dengan istri yang berlatar belakang miskin; suami berwatak kikir dalam pemberian nafkah; keluarga suami terlalu banyak mencampuri urusan anak yang sudah 
berumah tangga; ketergantungan suami kepada orangtuanya, sehingga ia tidak berani mengambil keputusan-keputusan mengenai rumah tangganya tanpa lebih dahulu meminta pertimbangan orang tuanya atau meniru tindakan orang tuanya yang pernah dialaminya; adanya salah pengertian, salah sangka di antara suami istri; adanya faktor akhlak. Dengan pesatnya pengembangan ilmu pengetahuan dan teknologi di sisi lain menguntungkan tetapi di sisi lainnya merugikan membawa kehancuran ahlak; gagal dalam berkomunikasi dengan pasangannya dan; tidak ada yang mau mengalah. Dari pemaparan di atas, hal ini merefleksikan bahwa gugatan perceraian yang diajukan perempuan merupakan tindakan terakhir setelah berbagai upaya dicoba dilakukan.

\section{E. Dampak Cerai Gugat pada Istitusi Keluarga}

Dari tiga kasus di atas yang secara singkat telah diuraikan, walaupun kelihatannya terasa berat untuk diambil keputusan, namun itulah keputusan yang sudah diambil apapun resikonya. Bagi ketiga kasus di atas secara ekonomi tidak tampak pengaruh bagi keluarganya, karena masing-masing sudah mempunyai pekerjaan. Mereka berusaha mencukupi kebutuhannya sendiri, walaupun kemudian mereka tinggal bersama orang tua masing-masing.

Untuk kasus SM dan SS ketika terjadi perceraian sudah mempunyai anak, masing-masing 1 orang. Menurut pengakuan keduanya semua kebutuhan anak-anak mereka tercukupi, walau tidak dikasih nafkah oleh mantan suami masing-masing. Bahkan ketika peneliti bertanya tentang bapaknya kepada anak SM yang sekarang telah berumur 5 tahun, ia mengatakan tidak mau bertemu dengan bapaknya.
Begitu juga dengan anak SS yang telah berusia sekitar 3 tahun terlihat gembira bersama ibu dan nenek/ kakeknya. Anak-anak mereka kelihatan tidak tertekan bersama ibu, namun secara sekilas ketika peneliti menanyakan tentang bapak mereka kelihatannya mereka malu-malu. SM dan SS sampai sekarang tidak habis pikir kenapa mantan suami mereka berperilaku kasar, masa bodoh dll terhadap mereka ketika menjadi istrinya. Namun mereka merasa senang karena bisa terlepas dari belenggu laki-laki yang sering menyakiti mereka, walaupun demikian mereka juga berterimakasih telah bisa dikarunia satu anak. Kemudian mereka berharap agar kelak ketika mempunyai suami dapat mendapatkan yang lebih baik lagi.

Perceraian pada akhirnya
berdampak pada cara pandang perempuan terhadap nilai dari institusi perkawinan. Kegagalan perkawinan yang telah dilalui perempuan direfleksikan sebagai sebuah proses pembelajaran diri dan pendewasaan diri. Namun demikian, perempuan cenderung lebih memilih menjadi single parent dan mempertimbangkan secara matang apabila akan menikah kembali.

\section{F. Peran Lembaga dalam Kasus Cerai Gugat}

Adanya lembaga penasihatan perkawinan yang bertujuan mewujudkan Keluarga Sakinah yaitu Badan Penasihatan Pembinaan dan Pelestarian Perkawinan (BP4) juga tidak bisa berjalan dengan baik "Laa yamuutu wa laa yahyaa", tidak bisa bermutu karena tidak ada biaya, karena wujudnya ada namun tidak berperan dalam masyarakat khususnya Kota Cilegon.

Pengadilan Agama setelah pindah ke Mahkamah Agung mengalami perubahan struktural yang signifikan. Berdasarkan UU No. 3 Tahun 2006 tugas

\begin{tabular}{l|l} 
Jurnal Multikultural \& Multireligius Vol. 16 & No. 1
\end{tabular} 
PA meliputi memeriksa, memutus, dan menyelesaikan perkara umat Islam dalam bidang perkawinan, waris, wasiat, hibah, wakaf, zakat, infaq, shadaqah, dan ekonomi Syariah. Setiap hari Pengadilan Agama Kota Cilegon menerima dan menyelesaikan banyak kasus-kasus tersebut. Namun beberapa sidang perceraian di PA Kota Cilegon kelihatannya belum maksimal dalam menanganinya, banyak persoalanpersoalan yang perlu ditelusuri dari masing-masing kasus yang diajukan masyarakat, namun karena keterbatasan SDM beberapa kasus seperti dianggap sama saja padahal perlu penangan khusus.

Peran lembaga terhadap cerai gugat relatif berubah ke arah yang makin objektif. Stigma negatif mengenai perceraian terutama untuk konteks kota, mulai berkurang. Masyarakat mulai melihat perceraian kasus per-kasus dalam memberi penilaian. Dari tiga kasus yang diteliti, dua kasus menunjukkan hal tersebut. Masyarakat kota yang makin kritis tidak lagi dengan serta merta memberi penilaian negatif terhadap tindakan perceraian, akan tetapi mencoba memahami lebih dalam sebelum memberikan penilaian. Hal tersebut berbeda pada masyarakat pinggiran dan tentu desa, yang masih cenderung merespon negatif kasus-kasus perceraian yang terjadi. (Bulan, 2015: 50)

Hal yang perlu dicermati terkait dengan peran PA sebagai institusi yang melakukan eksekusi atas permohonan perceraian. Tidak adanya kordinasi antara lembaga yang mengurus pernikahan (KUA), lembaga penasihatan pernikahan (BP4), dan lembaga yang mengeksekusi perceraian (PA); menyebabkan kehidupan berkeluarga dilihat sebagai sekuel yang terpisah: pernikahan satu hal, penyelesaian masalah satu hal, dan perceraian merupakan hal yang lain. Bukan hanya dilihat terpisah, akan tetapi terdapat perbedaan penanganan dan pendekatan. PA sebagai lembaga eksekusi pernikahan misalnya, cenderung melihat perceraian secara administrative dan yuridis semata. Karena hal itu kasuskasus perceraian (dalam hal ini cerai gugat) dapat diselesaikan dalam waktu sangat singkat, tanpa upaya-upaya untuk menjaga sakralisasi (keutuhan) pernikahan. Upaya untuk menghadirkan pihak tergugat pada kasus cerai gugat misalnya terlihat sangat lemah (pasif), padahal dengan ketidak-hadiran pihak tergugat mediasi tidak dapat dilakukan. Selain itu hak-hak perempuan untuk mendapatkan nafkah paska perceraian (terutama jika membawa anak) belum mendapat perlindungan, mengingat banyaknya putusan cerai gugat yang tidak mewajibkan suami untuk memberi nafkah untuk anak yang dibawa istri. Pendekatan administrative lagi-lagi menjadi prioritas (supaya kasus cepat selesai), yang menghilangkan makna substantive yang sedianya juga diperhatikan (menjaga generasi atau anak dari ekses negative perceraian). Keputusan cerai gugat yang menetapkan mantan suami untuk memberi nafkahpun ada kecenderungan dibiarkan tidak dilaksanakan, dengan tidak adanya mekanisme pelaksanaan putusan.

\section{Simpulan}

Ada beberapa faktor terjadinya cerai gugat, faktor tersebut tidak berdiri sendiri seperti yang disebutkan dalam hasil putusan PA, namun berkaitan antara satu dengan yang lainnya diantaranya adalah adanya nusyus (durhaka), baik suami, maupun istri; suami tidak pandai mengambil i'tibar dari latar belakang kehidupan istri sebelumnya; suami berwatak kikir dalam pemberian nafkah; keluarga suami terlalu banyak mencampuri urusan anak yang sudah berumah tangga; ketergantungan suami kepada orangtuanya; adanya 
salah pengertian, salah sangka di antara suami istri; adanyakemerosotan akhlak; gagal dalam berkomunikasi dengan pasangannya dan; tidak ada yang mau mengalah.

Dampak perceraian dari ketiga kasus di atas ada yang positif dan ada yang negative. Yang positif adalah istri dapat memperoleh status hukum yang jelas sehingga dapat melanjutkan kehidupan yang lebih baik; terbebas dari perseteruan yang terus berlangsung dengan suami; terbebas dari kekerasan fisik, psikologis, finansial, dan seksual; dapat bekerja lebih giat untuk membesarkan dan mendidik anaknya walaupun tidak bersama bapaknya. Sedangkan dampak negative nya antara lain: tumbuh kembang anak kurang perhatian dari seorang ayah karena jarang bertemu; tidak ada nafkah dari ayahnya dan; ada yang diteror oleh mantan suami.

Kondisi sosial masyarakat Kota Cilegon sangat berpengaruh terhadap pola perceraian di masyarakat Cilegon. Tindakan perceraian yang dilakukan oleh sebagian masyarakat Cilegon sangat kental dengan manusia yang belum siap menghadapi modernisasi. Ekonomi adalah salah satu variabel penting bagi masyarakat modern ternyata ia telah menjadi problem perceraian. Penduduk Masyarakat Kota Cilegon termasuk ke dalam kategori masyarakat semi modern, di mana daerah ini merupakan pusat pemerintahan maupun pusat pergerakan ekonomi. Dengan demikian menjadi suatu keharusan bagi penduduk dan masyarakatnya untuk menyesuaikan diri dengan konteks perubahan sosial. Konteks sosial inilah yang pada akhirnya banyak membentuk masyarakat Kota Cilegon untuk memiliki orientasi hidup yang pragmatis. Artinya sejauh tindakannya dapat membuat ia bertahan dan hidup nikmat di dalam modernitas, ia akan tetap terjaga dan pertahankan begitu pula sebaliknya. Jika suatu perubahan dapat membuat mereka merasa sengsara, mereka akan meninggalkannya termasuk juga dengan problem keluarga pada masyarakat Kota Cilegon di saat hidupnya mereka mapan dan bisa eksis dalm konteks perubahan sosial, mereka akan tetap bertahan kelestarian hidup rumah tangga dan jika tidak, maka perceraian adalah jalan alternatifnya.

\section{Ucapan Terima Kasih}

Di akhir tulisan ini, penulis sangat berterima kasih kepada Kepala Puslitbang Bimas Agama dan Layanan Keagamaan serta Kepala Badan Litbang dan Diklat Kementerian Agama RI yang telah memberikan kesempatan kepada penulis untuk melakukan penelitian tentang isu yang diangkat dalam tulisan ini, juga beberapa pihak dan informan yang terlibat dalam penggalian data dan informasi di dalamnya. Tidak ketinggalan, terima kasih juga penulis tujukan kepada Mitra Bestari Jurnal Harmoni yang telah memberikan catatan dan saran untuk perbaikan tulisan ini.

\section{Daftar Bacaan}

Abu Sahla dan Nurul Nazara, Buku Pintar Pernikahan. Jakarta: Penerbit Balanoor, tahun 2011

Badan Pusat Statistik Kota Cilegon, Cilegon Dalam Angka Tahun 2014

Bulan, Wahidah. R, Cerai Gugat pada Masyarakat Muslim, Studi Kasus di Kota Padang. 2015 
Cammack, M. dan T. Heaton. Kemajuan terbaru dalam Perceraian di Indonesia: Idealisme perkembangan dan Pengaruh Perubahan Politik. Makalah dalam Asian Journal of Social Science 39. 2011

Departemen Agama RI. Pedoman Penghulu, Direktorat Jenderal Bimbingan Masyarakat Islam. Jakarta, Tahun 2008

Erna Karim, "Pendekatan Perceraian dari Perspektif Sosiologi". Dalam Ihromi, Bunga Rampai Sosiologi Keluarga. Jakarta: Yayasan Obor Indonesia, 1999.

Ernaningsih, Wahyu dan Tim Peneliti Fakultas Hukum Universitas Sriwijaya. Tinjauan Yuridis Penyebab Perceraian di Kota Palembang. 2009

Ihromi, Tapi Omas (ed). Kajian Wanita dalam Pembangunan. Yayasan Obor Indonesia. Jakarta. 1995

Laporan Tahunan Mahkamah Agung RI - Tahun 2014.

Liliweri. Prasangka dan Konflik: Komunitas Lintas Budaya Masyarakat Multikutural. Yogyakarta: LkiS. 2005

Mosse, J.C. Gender dan Pembangunan. Hartian Silawati (penterjemah). Yogyakarta: Pustaka Pelajar. 1996

Mubarok, Achmad, Psikologi Keluarga,Dari Keluarga Sakinah Hingga Keluarga Bangsa. Jakarta: PT. Bina Rena Pariwara.Tahun 2007

Permatasari, Dewi. Faktor-Faktor yang Melatarbelakangi Pengambilan Keputusan Seorang Isteri untuk Mengajukan Gugatan Cerai. Skripsi di Program Studi Psikologi Jurusan Bimbingan Konseling dan Psikologi Fakultas Ilmu Pendidikan Universitas Negeri Malang, 2009

Ritzer, George dan Goodman, Douglas J. Teori Sosiologi Modern. Edisi ke Enam. Jakarta: Kencana. 2010

Said, Fuad. Perceraian Menurut Hukum Islam. Jakarta: Penerbit Putaka Husna. 1993

\section{Peraturan dan Perundang-Undangan:}

Undang-Undang Republik Indoensia Nomor 1 Tahun 1974 Tentang Perkawinan

Undang-Undang Republik Indoensia Nomor 7 Tahun 1989 tentang Peradilan Agama

Undang-Undang Republik Indoensia Nomor 3 Tahun 2006 tentang Perubahan Atas Undang-Undang Nomor 7 Tahun 1989 tentang Peradilan Agama

Peraturan Pemerintah Republik Indonesia Nomor 9 Tahun 1975 Tentang Pelaksanaan Undang-Undang Nomor 1 Tahun 1974 Tentang Perkawinan

Instruksi Presiden Republik Indonesia Nomor 1 Tahun 1991 tentang Kompilasi Hukum Islam (KHI) 